\title{
1. The philosophical view
}

\section{THE UNITARY PHILOSOPHERS: KANT AND HEGEL}

The tension between ideal and reality is perhaps the most striking feature of modern philosophy. This tension is particularly rich for the analysis of phenomena of power.

This is what we see in the two poles of modern unitary philosophy. The ideal world of a priori knowledge, first and foremost of Kant, opens the door to scientific positivism and scientism of the modern world.

Particularly useful in Kantian philosophy for this technicalscientific view regarding social phenomena and power are the $a$ priori synthetic concepts, that is, those concepts which, although not purely analytical (deductible from logic) and therefore requiring an analysis and verification in practice, can be defined ex ante, that is, even before the reality that they seek to interpret. ${ }^{1}$ This Kantian idea is undoubtedly the ultimate philosophical foundation for the entire classical and neoclassical theoretical construction ${ }^{2}$ and, as a result, of much of the current economic construction, glorifying economic power. Indeed, only a presumptive concept defined purely in the world of ideas and that can be compared (though not confronted) with reality (as is the synthetic concept a priori) is able, for example, to justify marginalism in microeconomics, despite its widely known unachievable assumptions. As is known, it

1 See for the concept of foremost synthetic concepts I. Kant, Kritik der Vernunft reinen, Hamburg, Felix Meiner, 1956, p. 48 et seq.

2 A terminological clarification is necessary. The term 'neoclassical', when used in economics, has multiple meanings, some designating interventionist ideas (Keynesian macroeconomics), and in other cases designating liberal schools. In antitrust law, it is common to identify the microeconomic neoclassical school with the ultra-liberal theorists of the Chicago School. It is in this sense that we use the term from this point on. 
is marginalism that is behind microeconomic neoclassicism and its indulgent view of economic power.

In Hegel, on the contrary, the reality seems self-explanatory and sufficient. Hegel seeks to make this ideal and idealized reality something which conforms to its universal dialectical rule. ${ }^{3}$ This universal dialectical rule has as its principle the opposition of the parts to the whole. And Hegel identifies this whole, which tends to prevail, exactly to the state which concentrates power. Although it does not refer to private power, Hegel makes a true apology of power (state) as an organizing force in society.

Here, it is important to note that in these classics of modern philosophy, power (economic), although present, is not immanent. And this is for a very simple reason. According to unitary philosophy, which seeks to reconstruct the world as a global unit, there is no room for distinction between being and ought to be. The loss of this unit in philosophy will have highly harmful consequences. Let me explain. In a science worried about the ultimate justification of phenomena, there must be certain ethical control on worldviews. What this means is that the ultimate foundations are not well explained without purposes. A simple example is quite enlightening: basic metaphysical questions such as why we exist cannot be answered without a view of the cause, which besides the last cause also includes the final cause. We are unable to understand why we exist without being conscious of for what we exist.

These highly intuitive observations suggest that ethics and analysis of reality must not become detached, at least in philosophy. It is precisely this feature that makes the greatness of global systems such as those of Kant and Hegel. It is precisely this characteristic that is criticized by utilitarians and pragmatists on one side and by philosophers of power on the other. The prevalence of these critics and their ideas will lead to the decay of the contemporary philosophical movement. 


\section{MODERN PHILOSOPHY: SPLIT BETWEEN ETHICS AND ANALYSIS OF REALITY}

Since the disappearance of Hegel - the last of the great unitary philosophers willing to present unitary explanations of reality philosophical movements begin to distinguish more clearly between 'is' and 'ought to be'. Philosophical schools become relevant either as ethical theories or as models to explain reality.

It is not surprising, then, that ethical schools (ought to be) began to be characterized by an absolute methodological individualism and the philosophy concerned with the explanation of ontological phenomena (is) began to be invaded by techno-scientism typical of the natural sciences.

From an ethical point of view, methodological individualism has its origins in the classical utilitarians (Locke, Bentham). For these authors, as the paradigm of individual purpose (or will) is fundamental in explaining the actions of the human being, the individual must guide its actions in this direction. Consequently, they go on to justify theories (economic) determining the 'ought to be' (right) from maxims (economic) of well-being.

Also relevant for ethics - which is not surprising - they become theories that place the individual and the power of his will at the centre of thinking about duty. This is the case with Nietzsche, for whom ethical principles are those derived from the behaviour of his superman. This individualist ethic - which glorifies the individual and his will - is just another step (ethically pretty extreme) to methodological individualism. ${ }^{4}$ The ground is prepared not only for economic power, but also and especially for totalitarian political power.

From an ontological perspective, the evolution is no less concerning. The analysis of 'being' in contemporary philosophy is predominantly based on techno-scientific studies. Whether in the analytic

4 The famous nihilism of Nietzsche, who denies all existing moral and religious ethics, ends up being transformed into an absolutely individual moral reconstruction, based on the will of power - see F. Nietzsche, Jenseits von Gut und Bòse, 3rd edition, Berlin, New York, de Gruyter, 1993, p. 339 et seq. Although in many passages of his work, this will is translated into simple habits of life, it is not in the end truly re-humanizing, at least not at the social level, as it does not explain forms of human co-existence. 
theory of Wittgenstein, which puts the analysis of forms of expression at the centre of philosophical investigation, both through logical deduction 5 and language theory, or in the philosophy of logical analysis. ${ }^{6}$ In both, the presence of logic and logical criteria for analysis of language sets the tone for the investigation. The study of the ultimate whys and the prospect of critical analysis of reality, for which the combination between the last cause and the final cause or between "being" and the purpose of being are fundamental, increasingly recede into the background.

\section{CRITICAL PERSPECTIVES}

Within this rather grim philosophical perspective, a line of critical thinking deserves mention. Interestingly, this line has its origins in (and until today remains in some way stuck to) the classical forms of philosophical thought.

The origins are in the dialectical thought of Hegel. Form of global analysis of reality, involving the future and the past, brings two very particular facets: determinism and criticism.

Both are used by Marxist analysis: the re-humanizing criticism, especially in the early works of Marx (called the young Marx), and determinism in its social and economic aspect, enshrined in the later works of Marx (especially in Das Kapital).

The latter can be criticized as it is today largely for its determinism and scientism. The concept of the inexorable march of history seems to dehumanize political and social relations, giving to power (economic and political) and its conquest a value as large as attributed by its rivals of modern philosophy.

Much richer and more studied in this century has been the prospect of social critique offered by the dialectic and initial studies 
of Marx. Most of the neo-Marxist construction in the volume of the so-called Frankfurt School is aimed at this review. ${ }^{7}$

This critical review of philosophical and sociological foundations of human behaviour presents two very interesting lines, rich in content. The first is followed by Hockheimer and the latter by his disciple, Habermas, who deepened and developed it. Hockheimer takes from the dialectic in particular the critical perspective regarding positivist social sciences. For him, the interdisciplinary and critical study is fundamental. Hence his insistence on creating an interdisciplinary institute, ${ }^{8}$ around which he would gather the major philosophers and sociologists who form the school of thought later called the Frankfurt School. For Hockheimer, true dialectical and critical discourse could only be achieved through interdisciplinary behaviour.

The second main line is that of Adomo, which uses the dialectic to criticize bourgeois, dehumanizing social relations, in line with studies of 'young Marx', interested in microsystems, the everyday life of the working class and their wealth - compared with the decay of bourgeois daily life.

Habermas, chief disciple of Hockheimer, extends greatly the reflections from the idea of interdisciplinarity. Firstly, we must remember that for Habermas, unlike Kant, the transcendental conditions of man's relationship with the world were born in empirical conditions. They were based on the natural history of the human species that defended their existence: working, communicating and suffering relationships of domination. According to Habermas, men had risen above nature when becoming speaking beings. The first phrase expresses the intention of a general consensus without coercion and that is expressed unambiguously. The author then introduces the idea of human existence as conversation and

7 For an interesting historical review of this school and the work of its leading representatives, see R. Wiggerhaus, Die Frankfurter Schule, 6th ed., München, Deutscher Taschenbuch Verlag, 2001.

8 It is the Institut für Sozialforschung, of Frankfurt University, founded by Felix Weil, which Hockheimer began to run from October 1930. See R. Wiggerhaus, Die Frankfurter Schule, op cit., p. 49. 
solidarity, which brings together all those with knowledge of the same language. ${ }^{9}$

At first, the theory acquires a very reformist nature. He advocates for a revolution of social relations through the introduction of cooperative parameters taken from the typical relations of the proletarian classes. In later works (mainly Theory and Practice), he defends forms of institutionalization of social communication, opening the doors to construction of social communication and exchanges in ways best suited to the existing social system. ${ }^{10}$

This turnaround does not make it impossible for Habermas to find very useful ideas (rare these days) for building a philosophical critique of social relations and also power relations. The idea of cooperation between individuals through communication is especially rich. And furthermore, Habermas identifies in communicative action a form of knowledge but not necessarily action. This, as we shall see, justifies forms of social and legal structures of societies that allow acquisition of knowledge and, from then on, give freedom of action. These forms are, as we shall see, generally speaking, procedural-economic, requiring a firm stance and a structural opposition to economic power. It is exactly from the dialectical refutation of classical theories or pre-established realities, including and especially power realities, that it is possible to state that a critical posture survives in the Frankfurt School.

9 See J. Habermas, Theorie des kommunikativen Handelns - Band I: Handlungsrationalitàt und gesellschaftliche Rationalisierung, Suhrkamp, 1999, p. 369 et seq.

10 See J. Habermas, Theory and practice, Boston, Beacon Press, 1973, p. 27. 